\title{
ANALYSIS OF THE ECONOMIC IMPACT ON A SPORTING EVENT. NEA REGIONAL COLLEGE GAMES. 2019 EDITION
}

\author{
Eva Muguerza \\ Economic and Social Observatory \\ of Sport and Physical Activity \\ National University of Misiones \\ Posadas, Misiones, Argentina \\ evi.muguerza@gmail.com \\ Tania Elizabet Ruff \\ Economic and Social Observatory \\ of Sport and Physical Activity \\ National University of Misiones \\ Posadas, Misiones, Argentina \\ taniaruff 08@hotmail.com
}

\author{
Natalia Ojeda \\ Economic and Social Observatory \\ of Sport and Physical Activity \\ National University of Misiones \\ Posadas, Misiones, Argentina \\ nataliaojeda86@gmail.com \\ Francisco Mauricio Rosenfeld y Sommer \\ Economic and Social Observatory \\ of Sport and Physical Activity \\ National University of Misiones \\ Posadas, Misiones, Argentina \\ mauricio.rosenfeld@gmail.com
}

Reception date: 09/23/2020 - Revision date: 01/08/2021 - Approval date: 01/11/2021

DOI: https://doi.org/10.36995/j.visiondefuturo.2021.25.01.006.en

\section{ABSTRACT}

This work is a contribution to the economics field of sport, considering the objective main application of the input-output model to the assessment of economic impact of a sporting events, taking as a case study "Regional University Games NEA 2019". In addition, it is proposed to study the different dimensions of the event's legacy, directly associated with the concept of impact.

Thus, this model makes it possible to evaluate the impact of a specific public policy or private demand to stimulate economic activity through a specific sector, sport in this case. To do so, they employ the multipliers of the Argentinian input product matrix and surveys to reveal the consumption of the organizers and participants of the event. All this, with the intention of adding rationality criteria to the decisions made by both public and private sports organizations.

It is important to mention that this study joins the lines of research widely studied by Salgado Barandela, Barajas and Sánchez Fernández (2017) on the subject developed mainly in Europe and the United States, not having found academic references in Argentina or Latin America on the subject.

The results indicate that these games have generated an additional boost to the demand for goods and services of the host city and the generation of both economic and social legacy has been verified.

\footnotetext{
"Visión de Futuro" Año 18, Volumen N$^{0} 25$ N 1, Enero - Junio 2021 - Pág 251-273

URL de la Revista: http://visiondefuturo.fce.unam.edu.ar/index.php/visiondefuturo/index

URL del Documento: https://visiondefuturo.fce.unam.edu.ar/index.php/visiondefuturo/issue/view/19

ISSN 1668 - 8708 - Versión en Línea

E-mail: revistacientifica@fce.unam.edu.ar
}

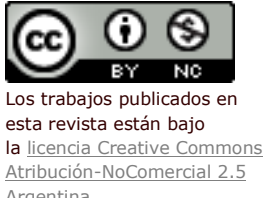

251 
KEY WORDS: Economic Impact; Sporting Event; College Games; Multipliers; Input - Product Matrix.

\section{INTRODUCTION}

\subsection{Measuring economic impact}

In the literature on the economics of sport, the importance of sport in the economy is discussed in terms of its registration in national accounts and the weight of the sector is measured based on its participation in GDP. Bosch, Murillo and Raya (2018) develop the theoretical framework and the measurement problems that arise when quantifying the economic importance of the sports sector and the economic impact of sporting events.

In this sense, it is appropriate to make a first distinction between these two ideas. " The weight of sport understood as an economic sector, ... can be explained as the economic value of the volume of activities that, directly or indirectly, are linked to sports activities " Bosch, Murillo and Raya (2018). From this approach, it is sought to measure both the supply and the demand for sport at an aggregate level, studying production, added value, occupation, expenditure, etc.

For its part, " the economic impact of sport is a broader concept and has to do with the expansion effects that this sector promotes within the global economic fabric" (Bosch, García and Murillo, 2018). Therefore, it is used to for measuring the effects on the local economy organizing sports events at different scales, both macro-events such as the organization of the Olympic Games as small - scale as the case study the NEA Regional University Games, 2019, which we will now call Games.

Now, to quantify this economic impact it is necessary to have a model that reflects the interrelationships between the different sectors that participate in the sector's value chain and for this the input-output tables or Input-Product Matrix are used, which has the ability to measure the effect of productive interdependence between sectors and calculate the multiplier that occurs when the economy has received a shock (boost or drop) in the demand of some sector (sports) and this translates into an adjustment of all related sectors within the economy .

Thus, the concept of multiplier appears that starts from the differentiation between the initial effect of the shock and the total or final effect that ends up being generated throughout the economy by the interrelation of all sectors as a consequence of the initial effect. In other words, the initial effect on a certain sector is amplified by the internal commercial flow of all the sectors that, directly and indirectly, are affected. For the development of this study, the multipliers

\footnotetext{
"Visión de Futuro" Año 18, Volumen $N^{0} 25$ N$^{0}$ 1, Enero - Junio 2021 - Pág 251-273

URL de la Revista: http://visiondefuturo.fce.unam.edu.ar/index.php/visiondefuturo/index

URL del Documento: https://visiondefuturo.fce.unam.edu.ar/index.php/visiondefuturo/issue/view/19

ISSN 1668 - 8708 - Versión en Línea

E-mail: revistacientifica@fce.unam.edu.ar
} 
calculated by Beyrne, G. (2015) have been used in their publication "Analysis of Productive Chains and Multipliers from the construction of the Matrix of Input - Argentine Product 2004".

Associated with the concept of economic impact, the idea of legacy appears, which makes sense when the effects over time of the organization of a sporting event are analyzed. Although this idea of legacy was born with the analysis of the Olympic Games and all the discussions associated with investment management and its use or amortization after the games are held, it is a perfectly applicable and measurable concept in smaller events such as it is the case study that is presented on this occasion.

When the economic impact is observed over time, it can be seen that there is a first moment in which the planning of both the event and the legacy and the management of investments is carried out, which will be the first consumptions that will be carried out to give form the Games. The concept of planning is defined in the Sports Administration Manual (2014) prepared by the Argentine Olympic Committee (COA) as “... a roadmap that guides us to reach our destination. It has a purpose, a direction and a program - why, where and when. In addition, it should cover what to do, who should do it and, by matching values with perspectives, how to do it" Franck Dick, former British national team coach.

After this first on stage, it's time to launch and enjoy the sporting event where sports activities (games or competitions) raised a performed fixture, the media coverage from the participation of media and / or use of social networks and the consumption of the spectators that can be locals and visitors.

Finally, at the end of the sporting event, what remains is the legacy, whose conceptualization is developed in the next section. To represent the relationship between impact and legacy, Figure №1 is presented with the temporal structure mentioned above.

\footnotetext{
"Visión de Futuro" Año 18, Volumen $N^{0} 25$ N$^{0}$ 1, Enero - Junio 2021 - Pág 251-273

URL de la Revista: http://visiondefuturo.fce.unam.edu.ar/index.php/visiondefuturo/index

URL del Documento: https://visiondefuturo.fce.unam.edu.ar/index.php/visiondefuturo/issue/view/19

ISSN 1668 - 8708 - Versión en Línea

E-mail: $\underline{\text { revistacientifica@fce.unam.edu.ar }}$
} 


\begin{tabular}{|l|l|l|}
\hline Before & During & Then \\
\hline $\begin{array}{l}\text { Planning } \\
\text { Investment management }\end{array}$ & $\begin{array}{l}\text { Fixture } \\
\text { Visitor consumption } \\
\text { Media impact }\end{array}$ & Legacies \\
\hline
\end{tabular}

Initial effect of consumption

Final effect of consumption

\section{Figure $\mathrm{N}^{\circ} 1$ : Economic impact of a sporting event \\ Source: Own elaboration}

In this way, a temporal analysis of the impact of sporting events has been carried out, segmenting it into three stages: before the event, when the initial effect occurs; during and after the event, when the final effect and legacy can be measured.

\subsection{Impact and legacy of sporting events: the concept of legacy}

There is a multiplicity of interpretations about the meaning of the "legacy" of sport and sporting events. In order to choose the most appropriate definition when reflecting this dimension of sport, five types of legacies have been grouped, selected and measured following Walters (2013) in economic and social legacy.

The economic legacy is the development of physical capital and businesses and is determined from the consumption and investments that the event has caused in terms of organization and start-up, adding the estimated consumption of visitors and spectators. At this point it is possible to calculate: Economic impact and multipliers; Impact on the hotel sector; Impact on the commercial sector; Impact on the tourism sector; Impact on the accounts of the National, Provincial and Municipal State; Development of new infrastructure, generation of physical capital and Adaptation of existing infrastructure, enhancement of physical capital. The development of tourism, business and the potential establishment of new industries in the host city are some of the effects that can happen to the celebration of sporting events.

For their part, Hughes, Kirk and Long (2010) investigate the concept of "social legacy" in macro sporting events applied to the London 2012 Olympic and Paralympic Games, and affirm that empirical studies on identification and evaluation of the wide range of aspects of the social legacy, which includes: quality of life, community cohesion, education, school exercises,

\footnotetext{
"Visión de Futuro" Año 18, Volumen No 25 N 1, Enero - Junio 2021 - Pág 251-273

URL de la Revista: http://visiondefuturo.fce.unam.edu.ar/index.php/visiondefuturo/index

URL del Documento: https://visiondefuturo.fce.unam.edu.ar/index.php/visiondefuturo/issue/view/19

ISSN 1668 - 8708 - Versión en Línea

E-mail: revistacientifica@fce.unam.edu.ar
} 
discovery of talents, job opportunities, enhancement of infrastructure, incentives for the population to practice sports.

Following the line proposed by Hughes, Kirk and Long (2010), this legacy is divided into:

- Legacy in education: has to do with educational resources, employee and volunteer training, research and preparation before events.

- $\quad$ Legacy in human capital: it consists of the training of those involved in the planning and implementation of an event.

- Social capital legacy: refers to social infrastructures based on social and group norms, which allow the population of mutual trust and cooperation and through which both groups and individuals obtain certain types of Coalter advantages (2007).

- Sports legacy: it is the most evident legacy of an event, it includes the incentive to physical activity, health, sports practices and habits that are generated from the influence of the event. At this point we incorporate sports practice with a gender perspective.

In order to make the event relevant beyond its realization, the legacy of an event should be a key component in planning, so work should start on building it before it starts. It thus follows that legacy constitutes a tool to create a competitive advantage for the event, offering added value to the entire environment and placing it even above the particular interest of each agent involved in the organization of the sporting event.

In the case of the 1992 Olympic Games in Barcelona, Brunet (2016) affirms that the legacy is synthesized both in the urban transformation of the city and in the changes in its economic structure as well as in its greater capitalization, outsourcing, internationalization, attractiveness, centrality, productivity and competitiveness. Barcelona has managed to strengthen and maintain the Olympic momentum, increase its activity and income, its quality of life and its social cohesion, and advance its strategic position.

" In this way, investments generate an impact that becomes the core of the legacy and in a global economy in which innovation and knowledge are the key to productivity, the preparation and celebration of a complex event with media projection drives competitiveness. In this way, the organization and holding of a mega event is an extraordinary benefit to the creative economy and society. " Brunet (2016).

In the development of the study, the indicators that allow quantifying the economic flow generated by the holding of the Regional University Games, NEA 2019, will be shown. From now on we will refer to the case study as the Games. This flow translates into greater demand for local goods and services, job creation and tax collection. Likewise, the economic (final impact of consumption on the local economy) and social legacies of the Games will be explored.

\footnotetext{
"Visión de Futuro" Año 18, Volumen No 25 N 1, Enero - Junio 2021 - Pág 251-273

URL de la Revista: http://visiondefuturo.fce.unam.edu.ar/index.php/visiondefuturo/index

URL del Documento: https://visiondefuturo.fce.unam.edu.ar/index.php/visiondefuturo/issue/view/19

ISSN 1668 - 8708 - Versión en Línea

E-mail: revistacientifica@fce.unam.edu.ar
} 


\section{DEVELOPMENT}

\subsection{Methodology}

In order to estimate the economic impact of the Games, the production multipliers were used for different branches of activity, calculated from the Argentine Input Product Matrix with data from 2004. This method is a useful tool for evaluating the impacts caused. by exogenous shocks in the final demand of a sector. In this way, the economic impact can be calculated, in this case of a sporting event, taking into account "the economic interdependence that exists between those economic activities that are reciprocally related to each other. " Cortés Fregoso and Sepúlveda Nuñez, (2006).

The Product Input Model (MIP) is made up of three basic tables:

- $\quad$ Table of intersectoral transactions.

- Matrix of Coefficients of Technical Requirements (or technical coefficients): it is calculated from the table of intersectoral transactions and expresses the direct requirements of inputs or value added of the sector that appears in the upper part of the column. This makes it possible to measure the increase in production in the face of an increase in the final demand of a single sector.

- Matrix of coefficients of direct and indirect requirements: from these coefficients it is possible to estimate the increase in total production that is generated from the increase in final demand, but this time considering the effect in all related sectors. The production multipliers are calculated on this matrix, decomposing them into their direct effect and their indirect effect.

In estimating the economic impact of the Games, the production multipliers for different branches of activity have been used, calculated for the matrix of Input product Argentina with data from 2004.

The sequential procedure has been as follows:

- From the information provided by the organizers, i identify and classify the consumption made for the launch of the sporting event

- Carry out the multiplication of these consumptions by the production multipliers of the open input-output model according to branch of activity 2004. Beyrne (2015)

- From a data collection instrument, identify and classify the spending intention of the participants of the sporting event

- Carry out the multiplication of these consumptions by the production multipliers of the open input-output model according to branch of activity 2004. Beyrne (2015)

“Visión de Futuro" Año 18, Volumen $\mathbf{N}^{\circ} 25$ N$^{\circ}$ 1, Enero - Junio 2021 - Pág 251-273

URL de la Revista: http://visiondefuturo.fce.unam.edu.ar/index.php/visiondefuturo/index

URL del Documento: https://visiondefuturo.fce.unam.edu.ar/index.php/visiondefuturo/issue/view/19

ISSN 1668 - 8708 - Versión en Línea

E-mail: revistacientifica@fce.unam.edu.ar 
- Relate the initial consumption of the organizers with the final effects of those consumption plus the final effects of the consumption of the event participants.

Meanwhile, it has designed an instrument to collect data associated with the participants of the event, in order to have information relevant $c$ on in order to calculate the intention of spending and characterize participants (players) under analysis and study specific questions such as the intention of the players' spending, sports habits and motivations, among others. For this second task, a survey was developed that revealed different dimensions associated with the event:

- $\quad$ Spending intent in different categories

- Touristic interest

- Socio-environmental information of the players (age, gender, career, institution)

- $\quad$ Sports habits (sports practice in childhood and adolescence)

- $\quad$ Federations (federated players)

To carry out this survey, you have selected a sample from the method of Simple Random Sampling (where each unit of the population has the same probability of selection), so that it is possible to know certain characteristics of the population low analysis (all the players participating in the Games) with the lowest possible cost in money, time and work. López Roldán (2015).

In order for the sample to be representative of the population and for the statistical analysis carried out to be reliable, the following conditions have been taken into account which, according to López Roldán (2015), must be met when selecting a sample, although it should be clarified that the analysis carried out in the present study is purely descriptive, without actually making statistical inference:

- $\quad$ That the sample includes part of the universe and not its totality,

- $\quad$ That the size of the sample is statistically proportional to the size of the universe,

- That there are no distortions in the selection process,

- $\quad$ That it is possible to test substantive hypotheses of relationships between variables.

The sample size is the number of complete responses that the survey receives and is called a sample because it only represents part of the group of people or population, whose opinions or behavior are analyzed to evaluate the impact of the event. In this case, a random sample was made, sending the form by WhatsApp to all the students who participated in the

\footnotetext{
"Visión de Futuro" Año 18, Volumen $N^{0} 25$ N$^{0}$ 1, Enero - Junio 2021 - Pág 251-273

URL de la Revista: http://visiondefuturo.fce.unam.edu.ar/index.php/visiondefuturo/index

URL del Documento: https://visiondefuturo.fce.unam.edu.ar/index.php/visiondefuturo/issue/view/19

ISSN 1668 - 8708 - Versión en Línea

E-mail: $\underline{\text { revistacientifica@fce.unam.edu.ar }}$
} 
Games. In this way, random responses were obtained from the total population of the target group.

The population under study consisted of the players who participated in the Games and amounted to 1,085 students. The confidence level was determined at $99 \%$ and the margin of error at $5 \%$. The size of the resulting sample with these parameters is 413 responses to the surveys and from the survey carried out we obtained responses from 501 students.

The calculation formula used is: $\mathrm{n}=\frac{\mathrm{z}^{2} \times \mathrm{P} \times \mathrm{Q} \times \mathrm{N}}{(\mathrm{N}-1) \times \mathrm{e}^{2}+\mathrm{z}^{2} \times \mathrm{P} \times \mathrm{Q}}$

taking into account that the sample size was estimated for a finite population and where a proportion is studied.

Where:

$\mathrm{n}=$ sample size;

$\mathrm{z}^{2}$ = the number of standard deviations indicating the level of confidence adopted, squared;

$\mathrm{e}^{2}=$ the sample error considered, squared;

$\mathrm{N}=$ the size of the population;

$\mathrm{P}=$ the proportion (or percentage) of individuals who have a characteristic;

$\mathrm{Q}=$ the proportion (or percentage) of individuals who do not have a characteristic.

\subsection{Results}

The Regional University Games seek to promote academic and personal development of college students with a tournament, federal, competitive, inclusive, innovative and supportive. They began in 2014 and have been taking place throughout the country for 6 years with the increasingly committed participation of the institutions that participate in the organization and management of the tournaments.

The following disciplines participate: chess, men's and women's athletics, men's basketball, men's and women's futsal, men's and women's soccer 11, men's and women's handball, women's hockey, men's and women's swimming, men's rugby (seven), men's and women's tennis, table tennis, men's and women's volleyball. And as promotional disciplines beach volleyball, 3×3 basketball, boating, cycling, fencing, archery, weightlifting, judo, rowing, taekwondo, sport shooting and yachting.

These Regional University Games are held in 8 regions, namely: Metropolitana Sur, NOA, Bonaerense, Metropolitana Norte, Cuyo, NEA, Metropolitana CABA and Patagonia, for one year and from each region the champions in each category play the national JUR the next year. In

“Visión de Futuro" Año 18, Volumen $\mathbf{N}^{0} 25$ No 1, Enero - Junio 2021 - Pág 251-273

URL de la Revista: http://visiondefuturo.fce.unam.edu.ar/index.php/visiondefuturo/index

URL del Documento: https://visiondefuturo.fce.unam.edu.ar/index.php/visiondefuturo/issue/view/19

ISSN 1668 - 8708 - Versión en Línea

E-mail: $\underline{\text { revistacientifica@fce.unam.edu.ar }}$ 
the case of JURNEAs, 11 institutions (public and private) from Formosa, Chaco, Corrientes and Misiones have participated during 4 days where around 1,100 students competed.

\subsubsection{Before the event}

To understand planning, the following questions arise in relation to event legacy planning:

- Legacy is not a natural consequence; it must be planned at the time the event is conceived. This means defining the legacy, assigning responsibilities, identifying stakeholders and planning strategies from the start of the event.

- It is important to recognize that, depending on various points of view, legacies can have positive and / or negative consequences. Therefore, you should try to maximize the positive legacies and minimize the negative ones.

The organization and planning of the Games was in charge of the headquarters, in this case the National University of Misiones with the support of the Federation of University Sport.

As part of the planning of the legacy, the Economic and Social Observatory of sport and physical activity UNaMs work on the identification and assessment of the impact economic and legacy. To do this, progress was made in two stages, an initial one with details of the expenses and activities involved in organizing the event, and a second stage, in which local institutions and guests were supported to quantify the expected expenses resulting from the event.

The income with which sporting events are usually financed comes from public and private sources, namely: National State, Provincial State, Municipal State, Sponsoring Companies, TV Rights, Tickets and Donations. This income can be given in currency or in kind such as access to sports facilities, security, health, clothing, sports equipment, medals, etc.

In relation to the management of purchases and investments, it was possible to verify that the main revenues that have allowed financing the Games have their origin in the Nation's Budget, within the Ministry of Education. Additionally, the government of the Province collaborated with monetary resources and in kind (sports facilities and accommodation). This time there was no income from tickets, television rights, or private sponsors. The administration of the resources was in charge of the UNaM, General Secretariat of Extension - Student Affairs.

Moreover, the expenses and consumption generated before and during the event were mainly in the city of Posadas. The information regarding the initial consumption associated with the organization of the sporting event is presented in Table 1.

\footnotetext{
"Visión de Futuro" Año 18, Volumen No 25 No 1, Enero - Junio 2021 - Pág 251-273

URL de la Revista: http://visiondefuturo.fce.unam.edu.ar/index.php/visiondefuturo/index

URL del Documento: https://visiondefuturo.fce.unam.edu.ar/index.php/visiondefuturo/issue/view/19

ISSN 1668 - 8708 - Versión en Línea

E-mail: revistacientifica@fce.unam.edu.ar
} 
Table №1: Consumption generated in the organization of the event in current pesos and in percentages

\begin{tabular}{|r|l|cr|c|}
\hline Item & \multicolumn{1}{|c|}{ Concept } & Amount in \$ & $\%$ of the total \\
\hline 1 & Foods & $\$$ & $438.110,00$ & $11 \%$ \\
\hline 5 & Textile products & $\$$ & $170.850,00$ & $4 \%$ \\
\hline 7 & Air transport, cargo and passeng & $\$ 1.289 .790,00$ & $33 \%$ \\
\hline 11 & Hotel and restaurant services & $\$ 1.172 .700,00$ & $30 \%$ \\
\hline 13 & Cinematography, radio and TV & $\$$ & - & $0 \%$ \\
\hline 15 & Business organization services & $\$$ & $605.319,00$ & $15 \%$ \\
\hline 21 & Insurance and taxes & $\$$ & $69.454,00$ & $2 \%$ \\
\hline 51 & Retail trade & $\$$ & $197.957,00$ & $5 \%$ \\
\hline & Totals & $\mathbf{\$ 3 . 9 4 4 . 1 8 0 , 0 0}$ & $\mathbf{1 0 0 \%}$ \\
\hline
\end{tabular}

Source: Own Elaboration

\subsubsection{During the event}

\section{A. Fixture}

The event organizers carry out the fixture, once the accreditations have been closed and depending on the athletes who presented themselves for each group or individual sport. The development of the games can be carried out in one venue or more depending on the availability of the city of adequate infrastructure for the sports in competition. As a result of the fixture and equipment performance is presented the Table No. 2 where information is summarized in the top three for sport and category.

\footnotetext{
"Visión de Futuro" Año 18, Volumen No 25 No 1, Enero - Junio 2021 - Pág 251-273

URL de la Revista: http://visiondefuturo.fce.unam.edu.ar/index.php/visiondefuturo/index

URL del Documento: https://visiondefuturo.fce.unam.edu.ar/index.php/visiondefuturo/issue/view/19

ISSN 1668 - 8708 - Versión en Línea

E-mail: revistacientifica@fce.unam.edu.ar
} 
Table №2: Results by sport and categories

\begin{tabular}{|c|c|c|c|c|c|c|}
\hline \multirow{2}{*}{ Results / Sport } & \multicolumn{3}{|c|}{ Women } & \multicolumn{3}{|c|}{ Man } \\
\hline & 10 & 2o & 3응 & 10 & $2^{\circ}$ & 3음 \\
\hline Chess & $\begin{array}{c}\text { No } \\
\text { participants }\end{array}$ & $\begin{array}{c}\text { No } \\
\text { participants }\end{array}$ & $\begin{array}{c}\text { No } \\
\text { participants }\end{array}$ & $\begin{array}{c}\text { National } \\
\text { University of } \\
\text { Formosa }\end{array}$ & $\begin{array}{c}\text { National } \\
\text { University of } \\
\text { Misiones }\end{array}$ & \begin{tabular}{|c|} 
National \\
University of \\
Chaco \\
Austral \\
\end{tabular} \\
\hline Athletics & $\begin{array}{c}\text { IESEF } \\
\text { Resistenci } \\
\text { a }\end{array}$ & $\begin{array}{c}\text { ISEF } \\
\text { Antonio } \\
\text { Alejandro } \\
\text { Alvarez }\end{array}$ & $\begin{array}{l}\text { National } \\
\text { University } \\
\text { of Nordeste }\end{array}$ & $\begin{array}{l}\text { ISEF + } \\
\text { IESEF }\end{array}$ & & $\begin{array}{c}\text { National } \\
\text { University of } \\
\text { Nordeste }\end{array}$ \\
\hline Basketball $3 \times 3$ & 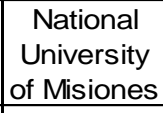 & $\begin{array}{c}\text { IESEF } \\
\text { Resistenci } \\
\text { a } \\
\end{array}$ & $\begin{array}{c}\text { Barceló } \\
\text { Santo } \\
\text { Tomé } \\
\end{array}$ & - & - & - \\
\hline Basketball & - & - & - & $\begin{array}{c}\text { National } \\
\text { University of } \\
\text { Chaco } \\
\text { Austral }\end{array}$ & $\begin{array}{c}\text { IESEF } \\
\text { Resistencia }\end{array}$ & $\begin{array}{c}\text { Instituto } \\
\text { Sup Antonio } \\
\text { Ruiz de } \\
\text { Montoya }\end{array}$ \\
\hline Soccer 11 & $\begin{array}{l}\text { National } \\
\text { University } \\
\text { of Formosa }\end{array}$ & $\begin{array}{c}\text { National } \\
\text { University } \\
\text { of Misiones }\end{array}$ & & $\begin{array}{c}\text { National } \\
\text { University of } \\
\text { Nordeste }\end{array}$ & $\begin{array}{c}\text { National } \\
\text { University of } \\
\text { Misiones }\end{array}$ & $\begin{array}{c}\text { IESEF } \\
\text { Resistencia }\end{array}$ \\
\hline Futsal & $\begin{array}{c}\text { IESEF } \\
\text { Resistenci } \\
\text { a }\end{array}$ & $\begin{array}{c}\text { National } \\
\text { University } \\
\text { of Misiones }\end{array}$ & $\begin{array}{c}\text { National } \\
\text { University } \\
\text { of Nordeste }\end{array}$ & $\begin{array}{c}\text { National } \\
\text { University of } \\
\text { Misiones }\end{array}$ & $\begin{array}{c}\text { National } \\
\text { University of } \\
\text { Nordeste }\end{array}$ & $\begin{array}{c}\text { ISEF } \\
\text { Antonio } \\
\text { Alejandro } \\
\text { Alvarez }\end{array}$ \\
\hline Handball & $\begin{array}{l}\text { National } \\
\text { University } \\
\text { of Formosa }\end{array}$ & $\begin{array}{c}\text { IESEF } \\
\text { Resistenci } \\
\text { a }\end{array}$ & $\begin{array}{c}\text { National } \\
\text { University } \\
\text { of Misiones }\end{array}$ & $\begin{array}{c}\text { National } \\
\text { University of } \\
\text { Nordeste }\end{array}$ & $\begin{array}{c}\text { National } \\
\text { University of } \\
\text { Chaco } \\
\text { Austral } \\
\end{array}$ & $\begin{array}{c}\text { ISEF } \\
\text { Antonio } \\
\text { Alejandro } \\
\text { Alvarez } \\
\end{array}$ \\
\hline Hockey & $\begin{array}{c}\text { National } \\
\text { University } \\
\text { of Misiones }\end{array}$ & $\begin{array}{c}\text { ISEF } \\
\text { Antonio } \\
\text { Alejandro } \\
\text { Alvarez } \\
\end{array}$ & $\begin{array}{c}\text { National } \\
\text { University } \\
\text { of Nordeste }\end{array}$ & $\begin{array}{c}\text { No } \\
\text { participants }\end{array}$ & $\begin{array}{c}\text { No } \\
\text { participants }\end{array}$ & $\begin{array}{c}\text { No } \\
\text { participants }\end{array}$ \\
\hline Swimming & $\begin{array}{l}\text { Instituto } \\
\text { Sup } \\
\text { Antonio } \\
\text { Ruiz de } \\
\text { Montoya }\end{array}$ & $\begin{array}{c}\text { IESEF } \\
\text { Resistenci } \\
\text { a }\end{array}$ & $\begin{array}{c}\text { ISEF } \\
\text { Antonio } \\
\text { Alejandro } \\
\text { Alvarez }\end{array}$ & $\begin{array}{c}\text { National } \\
\text { University of } \\
\text { Misiones }\end{array}$ & $\begin{array}{c}\text { IESEF } \\
\text { Resistencia }\end{array}$ & $\begin{array}{c}\text { ISEF } \\
\text { Antonio } \\
\text { Alejandro } \\
\text { Alvarez }\end{array}$ \\
\hline Rugby 7 & $\begin{array}{c}\text { No } \\
\text { participants }\end{array}$ & $\begin{array}{c}\text { No } \\
\text { participants }\end{array}$ & $\begin{array}{c}\text { No } \\
\text { participants }\end{array}$ & $\begin{array}{c}\text { ISEF } \\
\text { Antonio } \\
\text { Alejandro } \\
\text { Alvarez }\end{array}$ & $\begin{array}{c}\text { IESEF } \\
\text { Resistencia }\end{array}$ & $\begin{array}{c}\text { National } \\
\text { University of } \\
\text { Misiones }\end{array}$ \\
\hline Tennis & $\begin{array}{c}\text { ISEF } \\
\text { Antonio } \\
\text { Alejandro } \\
\text { Alvarez }\end{array}$ & - & - & $\begin{array}{c}\text { ISEF } \\
\text { Antonio } \\
\text { Alejandro } \\
\text { Alvarez }\end{array}$ & $\begin{array}{c}\text { National } \\
\text { University of } \\
\text { Misiones }\end{array}$ & - \\
\hline Table tennis & $\begin{array}{c}\text { No } \\
\text { participants }\end{array}$ & $\begin{array}{c}\text { No } \\
\text { participants }\end{array}$ & $\begin{array}{c}\text { No } \\
\text { participants }\end{array}$ & $\begin{array}{c}\text { National } \\
\text { University of } \\
\text { Nordeste }\end{array}$ & $\begin{array}{c}\text { National } \\
\text { University of } \\
\text { Misiones }\end{array}$ & $\begin{array}{c}\text { ISEF } \\
\text { Antonio } \\
\text { Alejandro } \\
\text { Alvarez }\end{array}$ \\
\hline Volleyball & $\begin{array}{l}\text { National } \\
\text { University } \\
\text { of Nordeste }\end{array}$ & $\begin{array}{c}\text { IESEF } \\
\text { Resistenci } \\
\text { a }\end{array}$ & $\begin{array}{c}\text { National } \\
\text { University } \\
\text { of Formosa }\end{array}$ & $\begin{array}{c}\text { IESEF } \\
\text { Resistencia }\end{array}$ & $\begin{array}{c}\text { National } \\
\text { University of } \\
\text { Formosa }\end{array}$ & $\begin{array}{c}\text { National } \\
\text { University of } \\
\text { Misiones }\end{array}$ \\
\hline
\end{tabular}

Source: Own elaboration

\footnotetext{
"Visión de Futuro" Año 18, Volumen $N^{0} 25$ N$^{0}$ 1, Enero - Junio 2021 - Pág 251-273

URL de la Revista: http://visiondefuturo.fce.unam.edu.ar/index.php/visiondefuturo/index

URL del Documento: https://visiondefuturo.fce.unam.edu.ar/index.php/visiondefuturo/issue/view/19

ISSN 1668 - 8708 - Versión en Línea

E-mail: revistacientifica@fce.unam.edu.ar
} 
As it is shown in the table, and I top 5 is formed by the IESEF Resistance to I OGRO position in podium with 14 medals, followed by the A to M with 13 medals, while the ISEF Antonio Alejandro Alvarez made podium in 11 competitions, followed by the National University of the Northeast that achieved 8 medals and finally the National University of Formosa with 5 medals.

It is interesting to note that the IESEF Resistance gained $32 \%$ of the medals with $12 \%$ of competitors with respect to the total of players from the Games, while the UNaM achieving 30\% of medals with $20 \%$ of participants. For its part, the distribution of medals was very even since of the 11 institutions that participated, 73\% made the podium with their teams or individual athletes showing a good competitive balance

\section{B. Mediatic impact}

It is important to identify the media degree that the event acquires, in order to estimate the potential or actual income from TV rights. If possible, the repercussions on the internet and social networks should also be identified: Website, YouTube, Facebook, Instagram, Twitter, WhatsApp.

Being an event that involved public and private institutes and universities, UN a M Transmedia decided to work on the dissemination and repercussion from digital platforms, that is, social networks and a website created especially for games: www.jur.UNaM.edu.ar . The site was created with the aim of being a repository where the productions of the social networks related to the meeting and information of relevance to it converge. It was put online for the public on Thursday, November 7, and from then until the first days of December there were 8,194 visits, 72 comments. The day with the most visits was Monday, November 11 with 4,064 visits.

A media coverage was made with a journalistic and documentary format. The idea was to tell "stories" that is, a narrative universe was developed through social networks generating stories and a site www.jur.UNaM.edu.ar. During the event, programs were made where what happened on the playing fields was recorded. The television products and documents that covered that narrative were uploaded, which takes place on media platforms (radio, podcast, etc.) and that universe is open and allows viewer co-authorship, generating content as well.

For the games, it was possible to integrate and merge the social communication careers of Misiones and Corrientes, students and teachers worked together to record the entire

\footnotetext{
"Visión de Futuro" Año 18, Volumen No 25 N 1, Enero - Junio 2021 - Pág 251-273

URL de la Revista: http://visiondefuturo.fce.unam.edu.ar/index.php/visiondefuturo/index

URL del Documento: https://visiondefuturo.fce.unam.edu.ar/index.php/visiondefuturo/issue/view/19

ISSN 1668 - 8708 - Versión en Línea

E-mail: revistacientifica@fce.unam.edu.ar
} 
event. UN a M Transmedia ensured the necessary equipment for the coverage of the games and a network and online coverage was considered. Pieces (videos and podcast) were generated that would serve multiple purposes. There was also a collaborative coverage in Oberá with UN a M Transmedia, the photography and audiovisual media career of the Faculty of Arts of the UN a M, Corrientes and Chaco.

More than 50 people participated in the productions, including students, technicians, cameramen, one of them from the audiovisual production center of Formosa, Chaco, Corrientes and Misiones. Teams from the communication, audiovisual and technological areas were integrated, there was a group of computer scientists supporting and updating the website. People with different roles, tasks working collaboratively and nurtured.

Productions were made as a summary of each day with information and interviews that came out in television format. This is how it worked in multiple areas, multiple formats and multiple screens.

\section{Player consumption}

Visitors will incur expenses during the course of the event and can be estimated from surveys prepared for this purpose. The items that are usually considered are: Accommodation, Transportation, Food, Tourism, Leisure and Shops.

The characteristics of the Games where accommodation, food and transport were included in the registration of participants of public universities, it was decided to evaluate the additional costs that would perform both local players and visitors from a table that the respondents completed with options of monetary ranges and activities in which they applied those resources.

The activities that were of interest to evaluate were:

- $\quad$ Leisure that includes night out and free time (confectioneries, discos, etc.).

- Tourism.

- $\quad$ Souvenir shops, presents, clothes.

- $\quad$ Food outside the hotel.

- Others.

\footnotetext{
"Visión de Futuro" Año 18, Volumen No 25 No 1, Enero - Junio 2021 - Pág 251-273

URL de la Revista: http://visiondefuturo.fce.unam.edu.ar/index.php/visiondefuturo/index

URL del Documento: https://visiondefuturo.fce.unam.edu.ar/index.php/visiondefuturo/issue/view/19

ISSN 1668 - 8708 - Versión en Línea

E-mail: revistacientifica@fce.unam.edu.ar
} 
Table № 3: Intention of expenditure by type of activity for players

\begin{tabular}{|c|c|c|c|c|c|c|c|c|c|c|}
\hline Spending Intent & \multicolumn{2}{|c|}{$\begin{array}{c}\text { de } \$ 0 \text { a } \\
\$ 500\end{array}$} & \multicolumn{2}{|c|}{$\begin{array}{l}\text { de } \$ 501 \\
\text { a } \$ 1.000\end{array}$} & \multicolumn{2}{|c|}{$\begin{array}{c}\text { de } \\
\$ 1.001 \mathrm{a} \\
\$ 1.500\end{array}$} & \multicolumn{2}{|c|}{$\begin{array}{c}\text { mas } \\
\text { de } \\
\$ 1.500\end{array}$} & \multicolumn{2}{|c|}{$\begin{array}{c}\text { Average } \\
\text { consumption }\end{array}$} \\
\hline Leisure (confectioneries, disco & 362 & $72 \%$ & 90 & $18 \%$ & 39 & $8 \%$ & 10 & $2 \%$ & $\$$ & 443 \\
\hline Tourism & 328 & $65 \%$ & 117 & $23 \%$ & 44 & $9 \%$ & 12 & $2 \%$ & $\$$ & 485 \\
\hline Shops (gifts, souvenirs, clothes & 344 & $69 \%$ & 103 & $21 \%$ & 37 & $7 \%$ & 17 & $3 \%$ & $\$$ & 469 \\
\hline Food (not included in the stay) & 309 & $62 \%$ & 136 & $27 \%$ & 48 & $10 \%$ & 8 & $2 \%$ & $\$$ & 501 \\
\hline Others & 399 & $80 \%$ & 66 & $13 \%$ & 24 & $5 \%$ & 12 & $2 \%$ & $\$$ & 394 \\
\hline \multicolumn{9}{|c|}{ Average estimated consumption } & $\$$ & 2.291 \\
\hline \multicolumn{9}{|c|}{ Total estimated consumption } & $\$$ & 2.486.188 \\
\hline
\end{tabular}

Source: Own elaboration (current currency 2019)

According to the information presented in Table №3, the ranges up to $\$ 1,000$ are those with the greatest presence in the estimated expenditure of the students. In particular, $72 \%$ of those surveyed stated that they would spend between $\$ 0$ and $\$ 500$ on leisure and $69 \%$ would spend on gift and souvenir shops. In tourism $65 \%$ of the players would be interested in spending in that first range as well.

The consumption profile of the students generates an estimated average expenditure of $\$$ 2,291 and when we calculate it for all the players who have participated in the games, the amount rises to $\$ 2,486,188$.- which have increased the demand for goods and services in the localities Hostesses, Posadas and Oberá, being the highest consumption in the City of Posadas.

\subsubsection{After the event}

\section{A. Economic legacy: Economic impact and multipliers}

Once all the expenses associated with the organization of the event and the estimated expenses of the players have been identified, it is time to calculate the initial and final effects of the event, $\mathrm{t}$ as shown in Table 4.

\footnotetext{
"Visión de Futuro" Año 18, Volumen $N^{0} 25$ N$^{0}$ 1, Enero - Junio 2021 - Pág 251-273

URL de la Revista: http://visiondefuturo.fce.unam.edu.ar/index.php/visiondefuturo/index

URL del Documento: https://visiondefuturo.fce.unam.edu.ar/index.php/visiondefuturo/issue/view/19

ISSN 1668 - 8708 - Versión en Línea

E-mail: $\underline{\text { revistacientifica@fce.unam.edu.ar }}$
} 
Table No. 4: Estimate of the final effects for expenses of the organization and the players

\begin{tabular}{|c|c|c|c|c|c|c|c|c|c|}
\hline Item & Concepto & Initial & Direct & Indirect & $\begin{array}{l}\text { Total } \\
\text { effect }\end{array}$ & $\begin{array}{l}\text { Consumption } \\
\text { Organization }\end{array}$ & $\begin{array}{c}\text { Player } \\
\text { consumption }\end{array}$ & $\begin{array}{c}\text { Total } \\
\text { Consumption }\end{array}$ & Total effect \\
\hline 1 & Foods & 1 & 0,699 & 0,534 & 2,233 & 438.110 & $\$ 1.024 .361$ & \$ 1.462 .471 & \$ 3.265.698 \\
\hline 5 & Textile products & 1 & 0,525 & 0,425 & 1,95 & 170.850 & $\$ \quad-$ & $\$ 170.850$ & $\$ \quad 333.158$ \\
\hline 7 & Air transport, cargo and passeng & 1 & 0,516 & 0,413 & 1,929 & $\$ 1.289 .790$ & $\$$ & $\$ 1.289 .790$ & $\$ 2.488 .005$ \\
\hline 11 & Hotel and restaurant services & 1 & 0,459 & 0,401 & 1,86 & $\$ 1.172 .700$ & $\$$ & $\$ 1.172 .700$ & $\$ 2.181 .222$ \\
\hline 13 & Cinematography, radio and TV & 1 & 0,481 & 0,346 & 1,827 & $\$ \quad-$ & $\$$ & $\$ \quad-$ & \$ $\quad-$ \\
\hline 15 & Business organization services & 1 & 0,479 & 0,333 & 1,812 & 605.319 & 525.716 & \begin{tabular}{|l|l|} 
& 1.131 .035
\end{tabular} & $\$ 2.049 .436$ \\
\hline 21 & Insurance and taxes & 1 & 0,477 & 0,305 & 1,782 & 69.454 & $\$$ & \$ $\quad 69.454$ & \$ 123.768 \\
\hline 51 & \begin{tabular}{|l|} 
Retail trade \\
\end{tabular} & 1 & 0,261 & 0,155 & 1,416 & 197.957 & 936.110 & $\$ 1.134 .068$ & $\$ 1.605 .840$ \\
\hline \multicolumn{6}{|c|}{ Totals } & 3.944 .181 & \$ 2.486 .188 & \begin{tabular}{|l|}
6.430 .368 \\
\end{tabular} & $\$ 12.047 .126$ \\
\hline
\end{tabular}

Source: Own elaboration (current currency of 2019)

Thus, $\$ 3,944,168$ was used to finance the consumption generated by the organization of the event and that made up the initial impact, along with $\$ 2,486,168$ that the players consumed.

All this translated into an increase in demand for mostly local goods and services, the impact of which after adjustments in the value chain of each consumption was $\$ 12,047,126$.This means that the initial consumption generated by the Games multiplied 3 times when the chain of expenses associated with the event was triggered.

\section{A.1 Public Sector Income}

When we consider the total consumption made on the occasion of the Games, $\$$ $12,047,126$.- we can calculate the estimated income from tax collection, at the different levels of government:

- $\quad \operatorname{VAT}(21 \%$ on consumption).

- $\quad$ IIBB $(4.5 \%$ of turnover).

- $\quad$ Municipal Taxes (0.01\% on billing discounting IIBB).

The tax revenue from consumption generated by the event totaled $\$ 3,073,222$ of which in the Province of Misiones remain \$ 543.326.-

\section{A.2 Development of new infrastructure and / or adaptation / amortization of existing infrastructure}

In these games, the adaptation, repair or generation of infrastructure was not necessary. Existing physical capital was used.

\footnotetext{
"Visión de Futuro" Año 18, Volumen $N^{0} 25$ N$^{0}$ 1, Enero - Junio 2021 - Pág 251-273

URL de la Revista: http://visiondefuturo.fce.unam.edu.ar/index.php/visiondefuturo/index

URL del Documento: https://visiondefuturo.fce.unam.edu.ar/index.php/visiondefuturo/issue/view/19

ISSN 1668 - 8708 - Versión en Línea

E-mail: revistacientifica@fce.unam.edu.ar
} 


\section{A.3 Increase in tourism}

Given the importance of this economic sector, we consider it pertinent to carry out a complementary analysis of the effects of the event on the hotel business. And for this, personal interviews have been carried out with the management of these establishments to contextualize the sector and correctly analyze the impact of the event in this area.

In the city of Posadas, 49 establishments totaling 1,315 rooms and 3,375 beds have been registered for 2016 according to the Statistical Yearbook of the Province of Misiones 2016 IPEC). Of these 49 establishments, 3 were partially occupied for the event, that is, $6 \%$ of the supply of hotels in the city.

Interviews were conducted with the hotels to estimate the income and occupancy generated by the Games. The results can be seen in Table №5 where the relevant indicators have been selected to measure hotel activity based on the increase in demand generated by the Games.

Table $N^{\circ}$ 5: Hotel activity indicators in the week of JURNEA2019

\begin{tabular}{|l|c|}
\hline Total places occupied by the event in 3 Hotels of the City of Posadas in the 4 days & 1.548 \\
\hline Average occupancy level during the days of the event in the 3 Hotels & $81 \%$ \\
\hline Occupancy growth rate compared to the previous year & $132 \%$ \\
\hline Income generated to the Hotels of the city of Posadas by the event, for acco & $\mathbf{\$ 1 . 1 7 2 . 7 0 0}$ \\
\hline Occupancy of the available supply of hotels in the City of Posadas (49) & $6 \%$ \\
\hline
\end{tabular}

Source: Own elaboration

The first interesting conclusions that we can highlight are that: a) The Games resulted in an occupancy of $81 \%$ in the hotels used. And that represented revenue from the $\$ 1$ event alone. 172,700 for accommodation between the three hotels; b) The estimated occupancy rate increased by $132 \%$ compared to 2018 , generating additional income for these hotels.

It is important to note that the average stay of tourists or visitors in Posadas is 1.7 days, according to the data provided by IPEC in the report mentioned above. Therefore, an event that occupies the hotel capacity for four days is relevant for activity in the sector.

\footnotetext{
"Visión de Futuro" Año 18, Volumen $N^{0} 25$ N$^{0}$ 1, Enero - Junio 2021 - Pág 251-273

URL de la Revista: http://visiondefuturo.fce.unam.edu.ar/index.php/visiondefuturo/index

URL del Documento: https://visiondefuturo.fce.unam.edu.ar/index.php/visiondefuturo/issue/view/19

ISSN 1668 - 8708 - Versión en Línea

E-mail: revistacientifica@fce.unam.edu.ar
} 


\section{B. Social legacy: human capital development}

\section{B.1 Legacy in education - education of athletes}

In this space, the demographic and sports profile of the players has been studied. It is possible to observe that the age with the highest participation range $(38 \%)$ is the one that goes from 21 to 23 years, followed by the range of 18 to 20 years with $27 \%$. In third place, there is the range that goes from 24 to 26 years with a $20 \%$ and finally, athletes with 27 years or more with a participation of $15 \%$.

Table №6 presents the information regarding the proportion of players by career grouped in the sciences of physical education, engineering, education sciences, health sciences, economics, exact and natural sciences, human sciences and social, legal sciences, veterinary, forestry and agricultural sciences.

The data show that the largest number of players (19\%) are from physical education sciences, followed very closely with $18 \%$ by engineering, educational sciences (16\%) and health sciences $(14 \%)$.

Table No. 6 Players grouped by science teams' visitors

\begin{tabular}{|l|c|c|}
\hline \multicolumn{1}{|c|}{ Science } & Quant. & $\begin{array}{c}\text { participation } \\
\%\end{array}$ \\
\hline Physical education & 96 & $19 \%$ \\
\hline Engineering & 90 & $18 \%$ \\
\hline Educational sciences & 78 & $16 \%$ \\
\hline Health Sciences & 71 & $14 \%$ \\
\hline Economic Sciences & 50 & $10 \%$ \\
\hline Exact and natural sciences & 37 & $7 \%$ \\
\hline Human and social sciences & 34 & $7 \%$ \\
\hline Legal sciences & 17 & $3 \%$ \\
\hline Veterinary, Forest and Agricultural Sci & 12 & $2 \%$ \\
\hline Other & 16 & $3 \%$ \\
\hline \multicolumn{1}{|c|}{ Totals } & $\mathbf{5 0 1}$ & $\mathbf{1 0 0 \%}$ \\
\hline
\end{tabular}

Source: Own Elaboration

\section{B.2 Legacy in human capital}

It consists of training those involved in the planning and implementation of an event. It is considered a desirable legacy since it generates the Know How for the organization of other events in the future (volunteers, managers, business networks that are functional to the "Visión de Futuro" Año 18, Volumen $N^{0} 25$ N$^{0}$ 1, Enero - Junio 2021 - Pág 251-273 URL de la Revista: http://visiondefuturo.fce.unam.edu.ar/index.php/visiondefuturo/index URL del Documento: https://visiondefuturo.fce.unam.edu.ar/index.php/visiondefuturo/issue/view/19 ISSN 1668 - 8708 - Versión en Línea 
event). Regarding the Volunteer, during volunteers worked 15 games for accreditation, and in all sports collaborating with teachers, as well as control tables.

Furthermore, the development of knowledge for the organization of sporting events is important to ensure the success of the present and future games. In the case of NUG, the organizing team has a background in multiple events and one of the steps taken in this case was the coordination with different areas Government.

\section{B.3 Social capital legacy - Sense of belonging of the population}

It is interesting to understand the motivations of the students to participate in the Games, for this an open question was asked in the questionnaire and the 501 responses were grouped according to the most relevant motivations that are exposed in Table №7.

Table $N^{\circ}$ 7: Pain motivators in JURNEA2019

\begin{tabular}{|l|c|c|}
\hline \multicolumn{1}{|c|}{ Reason } & Quantity & $\%$ \\
\hline Passion / love for sports and competition & 188 & $38 \%$ \\
\hline $\begin{array}{l}\text { Represent the institution / team and } \\
\text { access the nationals }\end{array}$ & 109 & $22 \%$ \\
\hline $\begin{array}{l}\text { Experience in sports, culture, tourism, } \\
\text { education }\end{array}$ & 96 & $19 \%$ \\
\hline Does not respond & 65 & $13 \%$ \\
\hline Friendship, companionship, call, teamwork & 43 & $9 \%$ \\
\hline Total surveys & $\mathbf{5 0 1}$ & $\mathbf{1 0 0 \%}$ \\
\hline
\end{tabular}

Source: Own elaboration

The main stimulus arises from the love of sports and competition (38\%). And the possibility of representing the institution of origin and of qualifying for national games is the second motivation in order of importance, $22 \%$.

\section{B.4 Sports legacy}

\section{B.4.1 Sports practice in the population (sports habits)}

Bertrán (2005) makes the following considerations:

“... traditionally, sport has been seen as a playful activity based on physical effort and competition that distracts children and adolescents from academic performance,

“Visión de Futuro" Año 18, Volumen $\mathbf{N}^{0} 25$ No 1, Enero - Junio 2021 - Pág 251-273

URL de la Revista: http://visiondefuturo.fce.unam.edu.ar/index.php/visiondefuturo/index

URL del Documento: https://visiondefuturo.fce.unam.edu.ar/index.php/visiondefuturo/issue/view/19

ISSN 1668 - 8708 - Versión en Línea

E-mail: revistacientifica@fce.unam.edu.ar 
eminently mental, but also based on effort and competition. In the collective imagination of parents, educators, social and political managers, the formative activity of adolescents corresponds fundamentally to intellectual performance, not physical performance ".

Multiple studies break the myth about the negative relationship between academic performance and physical activity and sport, and further reinforce the positive role that systematized physical practices have in the personal growth of adolescents and in their social fit. From this line of thought, it follows that physical activity and sport should be the guiding principle of public policies focused on promoting the regular practice of sport in adolescence and thus being able to collaborate effectively in the personal growth of young people.

When focusing the analysis on the players and their sports habits, whose information is summarized in Table №8, it can be observed that of the total surveyed, $67 \%$ assure that they have regularly practiced sports between the ages of 13 and $17 ; 50 \%$ who have done it between the ages of 18 and 25; and 44\% in childhood (between 5 and 12 years of age). Additionally, it has been found that $99 \%$ of the players have participated in high school sports games, showing a very high correlation with competitive continuity in sport.

Clearly, the sports habitats incorporated throughout childhood and especially in adolescence determine the continuity of the practice in youth. Adolescence is configured as a key stage in the development process of an individual; This specific treatment receives specialized care in the medical, psychological, social, cultural, educational and economic fields (as consumers).

Table No. 8: Sports habits

\begin{tabular}{|c|c|c|}
\hline Age & \multicolumn{2}{|c|}{ Players } \\
\hline 05 to 12 years & 222 & $44 \%$ \\
\hline 13 to 17 years & 334 & $67 \%$ \\
\hline 18 to 25 years & 253 & $50 \%$ \\
\hline over 26 years & 49 & $10 \%$ \\
\hline Total surveys & $\mathbf{5 0 1}$ & \\
\hline
\end{tabular}

Source: Own elaboration

In this sense, it is observed that sports practice is transversal to all these dimensions and of great importance in the integral development of the individual. In relation to the sports projection of the players, it was possible to observe that $49 \%$ of the participants of the Games are federated.

\footnotetext{
"Visión de Futuro" Año 18, Volumen $N^{0} 25$ N$^{0}$ 1, Enero - Junio 2021 - Pág 251-273

URL de la Revista: http://visiondefuturo.fce.unam.edu.ar/index.php/visiondefuturo/index

URL del Documento: https://visiondefuturo.fce.unam.edu.ar/index.php/visiondefuturo/issue/view/19

ISSN 1668 - 8708 - Versión en Línea

E-mail: revistacientifica@fce.unam.edu.ar
} 


\section{B.4.2 Sport Analysis with perspective of gender}

Another interesting indicator arises when evaluating the participation of men and women in sport. According to the data obtained, female participation (42\%) has not yet reached parity. This part of the analysis is important for the definition of incentives for female participation in university sports.

The gender perspective makes it possible to broaden the analysis of the games and considering that sport is one of the areas where the most has been done for gender equality, the results seem encouraging.

As can be seen in Table №9, it is notable that the proportion of men exceeds women by a few points in all age ranges, but it is striking in the range $24-26$ years where men reach $73 \%$ of participation in relation to $27 \%$ of women.

Table № 9: Gender perspective - Age range of the participants

\begin{tabular}{|c|c|c|c|c|c|}
\hline Age & \multicolumn{2}{|c|}{ Women } & \multicolumn{2}{c|}{ Men } & Total \\
\hline $\begin{array}{c}\text { 18-20 years } \\
21-23 \text { years }\end{array}$ & 81 & $48 \%$ & 71 & $52 \%$ & $\mathbf{1 3 7}$ \\
\hline $\begin{array}{c}24-26 \text { years } \\
27 \text { or more } \\
\text { years }\end{array}$ & 38 & $27 \%$ & 73 & $57 \%$ & $\mathbf{1 8 8}$ \\
\hline Total surveys & $\mathbf{2 1 2}$ & 38 & $50 \%$ & $\mathbf{7 6}$ \\
\hline
\end{tabular}

Source: Own elaboration

Meanwhile, Table №10 presents the information related to sports habits, that is, to the practice of sports throughout childhood, adolescence and youth. In this case, the participation of men knew $r$ to all age ranges in women.

Table № 10: Gender perspective - Sporting habits of the participants

\begin{tabular}{|l|c|c|c|c|r|}
\hline \multicolumn{1}{|c|}{ Age } & \multicolumn{2}{|c|}{ Women } & \multicolumn{2}{c|}{ Men } & Total \\
\hline 05 to 12 years & 85 & $38 \%$ & 137 & $62 \%$ & $\mathbf{2 2 2}$ \\
\hline 13 to 17 years & 135 & $40 \%$ & 199 & $60 \%$ & $\mathbf{3 3 4}$ \\
\hline 18 to 25 years & 93 & $37 \%$ & 160 & $63 \%$ & $\mathbf{2 5 3}$ \\
\hline over 26 years & 17 & $35 \%$ & 32 & $65 \%$ & $\mathbf{4 9}$ \\
\hline Total surveys & $\mathbf{2 1 2}$ & & $\mathbf{2 8 9}$ & & \\
\hline
\end{tabular}

Source: Own elaboration

\footnotetext{
"Visión de Futuro" Año 18, Volumen $N^{0} 25$ N$^{0}$ 1, Enero - Junio 2021 - Pág 251-273

URL de la Revista: http://visiondefuturo.fce.unam.edu.ar/index.php/visiondefuturo/index

URL del Documento: https://visiondefuturo.fce.unam.edu.ar/index.php/visiondefuturo/issue/view/19

ISSN 1668 - 8708 - Versión en Línea

E-mail: revistacientifica@fce.unam.edu.ar
} 


\section{CONCLUSION}

At present, sports organizations, understand ministries or sports secretariats, clubs, associations, federations, are in charge of managing sports activity and their function is focused on the development of sports, the creation or improvements of infrastructure, management of economic and human resources and the organization of events among other activities. These organizations go through decision-making processes in which they must assign priorities and to do so in a rational way they need to have adequate tools for information management. The impact analysis through the use of multipliers represents a significant tool for making decisions when promoting certain productive sectors and being able to measure the effect of the total shock on the economy. (Beyrne, 2015)

Inspired by this, this study offers two tools: on the one hand, the use of the multipliers of the Input-Product matrix and on the other, surveys to collect quality information, which will allow sports organizations to evaluate the economic impact and the legacy of the sporting events they organize. With specific indicators that highlight the economic and social facet of sport, such as the media impact, generation of human capital, social capital, sports habits and others that are not normally seen.

Specifically, the impact analysis model consists of a series of differentiated steps that are presented sequentially and that, starting from the direct and indirect effect, allow obtaining the total economic impact for the reference territorial area that is proposed in the study. It should be noted that this tool has been developed with the aim of facilitating and improving the performance of this type of study in the sports field, but it is also applicable to cultural, educational, recreational, etc. events that attract visitors.

However, two aspects that can generate controversy in the applications of the model cannot be omitted, which are related to the assumptions underlying the input-output model on the one hand and the age of the Input-Output Matrix of Argentina, on the other.

K. Porter and Fletcher (2008) present a series of criticisms of the use of the input output model to measure long-term impacts on the economy, in relation to the production function and the input supply functions. Regarding the assumptions underlying the model, it is not possible to make adjustments to correct this weakness.

They also point out that the estimates are made from surveys of attendees or projections of past events that tend to overestimate visitor spending. In the impact study of the Games,

\footnotetext{
"Visión de Futuro" Año 18, Volumen No 25 N 1, Enero - Junio 2021 - Pág 251-273

URL de la Revista: http://visiondefuturo.fce.unam.edu.ar/index.php/visiondefuturo/index

URL del Documento: https://visiondefuturo.fce.unam.edu.ar/index.php/visiondefuturo/issue/view/19

ISSN 1668 - 8708 - Versión en Línea

E-mail: revistacientifica@fce.unam.edu.ar
} 
$86.16 \%$ of the surveys were answered by visitors, which is why the data on new expenses attributable to the event is considered robust.

The second aspect to consider is the use of a 15-year-old matrix, which may not be adequately reflecting current intersectoral relationships. In this sense, Porta F. (20016) analyzes that the prevailing growth regime since 2003 , which has favored a very positive evolution in most socioeconomic indicators and in the population's quality of life, was not supported by a structural change significant. In general terms, the composition of GDP has not changed significantly in relation to the 1990s. In turn, analyzing each of these sectors, there have not been significant changes in the type, range and variety of products or services produced.

Saving these observations, the necessary recapitulation process allows us to draw a series of conclusions regarding the celebration of sporting events and the quantification and measurement of the economic impact generated by them. In terms of the study carried out, it is verified that the Games have left a valuable human capital legacy in terms of training students in health, design, tourism and communication. Likewise, the organizing team continues to develop skills for the planning and execution of sporting events (know how), strengthening ties with state agencies necessary for the realization of future sporting events in the province of missions.

The need to plan a fixture was expressed, which allows the visit to places of tourist interest that the province has and which would allow a greater economic effect to be expected in the short and long term. This sporting event also had a favorable impact on the coffers of the provincial and national states, generating additional income from the consumption of both organizers and visitors.

In conclusion, the almost $\$ 4,000,000$ applied to the organization of the Games translates into more than $\$ 12,000,000$ in economic movement from the generation of consumption by visitors, event providers (direct effects) and event providers. inputs for those suppliers (indirect effects). In other words, for each peso applied to the event, the economy receives a boost in its demand that is multiplied 3 times in income for the entire value chain that is generated from that initial demand.

Finally, this study serves as the basis for future research on the factors that contribute to community sports, analyzes with a gender perspective, the development of human and social capital, sports tourism, among others. All these issues directly related to the concept of impact and legacy, seeking to identify the incidence of sport on aspects of economic and social relevance, in order to design and evaluate both public and private strategies that allow improving the rate of sports participation in our society.

\footnotetext{
“Visión de Futuro" Año 18, Volumen N$^{0} 25$ No 1, Enero - Junio 2021 - Pág 251-273

URL de la Revista: http://visiondefuturo.fce.unam.edu.ar/index.php/visiondefuturo/index

URL del Documento: https://visiondefuturo.fce.unam.edu.ar/index.php/visiondefuturo/issue/view/19

ISSN 1668 - 8708 - Versión en Línea

E-mail: revistacientifica@fce.unam.edu.ar
} 


\section{REFERENCES}

Please refer to articles in Spanish Bibliography.

\section{BIBLIOGRAPHICAL ABSTRACT}

Please refer to articles Spanish Biographical abstract.

\footnotetext{
"Visión de Futuro" Año 18, Volumen $N^{0} 25$ N$^{0}$ 1, Enero - Junio 2021 - Pág 251-273

URL de la Revista: http://visiondefuturo.fce.unam.edu.ar/index.php/visiondefuturo/index

URL del Documento: https://visiondefuturo.fce.unam.edu.ar/index.php/visiondefuturo/issue/view/19

ISSN 1668 - 8708 - Versión en Línea

E-mail: $\underline{\text { revistacientifica@fce.unam.edu.ar }}$
} 